\title{
Moral values of professional activity in information society*
}

\author{
V.A. Tsvyk, ${ }^{1}$ I.V. Tsvyk ${ }^{1,2}$ \\ ${ }^{1}$ Peoples' Friendship University of Russia (RUDN University) \\ Miklukho-Maklaya St., 6, Moscow, 117198, Russia \\ ${ }^{2}$ Moscow Aviation Institute (National Research University) \\ Volokolamskoe Shosse, 4, Moscow, 125993, Russia \\ (e-mail: tsvyk-va@rudn.ru; tsvykirina@mail.ru)
}

\begin{abstract}
The article identifies the moral values of professional activity in information society on the basis of the systematic approach. Informatization of society in the $21^{\text {st }}$ century entered a new stage of its development. The new information environment aims at forming certain ideological and axiological priorities, according to which the value characteristics of information society change and reproduce. One of the most important value areas in information society is professional activity, whose moral values mutual responsibility, loyalty to duty, tolerance, decency, and focus on cooperation - develop during personal professionalization. Subsequently, in the course of professional work, professional conscience, duty, responsibility, dignity, tact, etc. develop. Professionalism is the most important moral value of professional activity; however, it should not be limited to the sum of professional knowledge and skills. A true professional has a developed, based on value orientations, moral culture, deep understanding of his professional duty, the most scrupulous attitude to professional honor, a high degree of professional responsibility. The success of his activities, the integrity of his personality, and his creative self-expression in the chosen profession depend on his professional and moral principles - their unity and consistency. The task of forming the professional values of an employee is an essential component of personal professionalization in order to achieve an optimal combination of traditional and creative elements, of specific professional experience and public morality. From the ethical perspective, professionalism in the ability to ensure harmony of professional activity and its moral evaluation, readiness for worthy deeds in any professional situations.
\end{abstract}

Key words: values; professional activity; information society; moral values; professionalism; personal professionalization; professional conscience; professional duty; professional responsibility

Labor values and values of professional activity, their imperative power as a social regulator, and conditions of development cannot be understood out of context of common life values, especially cultural values. Contemporary society is characterized by the acceleration of technological development, creation of new intellectual products, and transformation of information into the most important global resource of humanity. Researchers associate these changes with informatization and declare the transition of the global civilization to a new state - information society, which brings to the philosophical dis-

* C V.A. Tsvyk, I.V. Tsvyk, 2019.

The research was financially supported by the RUDN University. Project No. 101404-0-000 "Youth development: The problem of values forming in information society".

The article was submitted on 04.05.2019. The article was accepted on 07.06.2019. 
course concepts "information society" and "knowledge society". Together with matter and energy information becomes the most important global resource of mankind which cannot be reduced to two others. The new information environment aims at forming certain ideological and axiological priorities, according to which value characteristics of information society change and reproduce, and one of the most important value areas today is the professional activity of the individual.

\section{Social consequences of informatization}

According to Z. Brzezinski, D. Bell, A. Toffler and other scholars, information society is a kind of post-industrial society: it develops with the dominance of the "fourth" information sector of the economy, which follows three well-known sectors - agriculture, industry, and services. However, they argue that capital and labor, the basis of industrial society, give way to information and knowledge in information society. There are various indicators of the transition to the information stage. The share of population engaged in the service sector can serve as a criterion for the transition to the post-industrial stage and further to the information stage: if more than $50 \%$ of population are employed in the service sector, then the post-industrial stage began; if more than $50 \%$ are employed in the field of information services, then the society became information. For instance, the USA entered the postindustrial stage in 1956, and became information society in 1974. In the 1980s, the Japanese Institute of the Information Society was created in Japan. Its director, J. Masuda, argues that information technologies determine radical changes in value orientations: from narrow, direct, selfish they will turn into ethical, taking into account the interests of all humankind; due to informatization of all activities and emergence of the new intellectual, contemporary society will turn into a polycentric global society based on collectivism and competition.

Many Russian authors believe that in such concepts there are obvious elements of social utopia; however, they argue that it is not a reason to reject the very study of new trends in the development of society. Thus, A.I. Rakitov identifies the following features of information society: a) accessibility of information; b) real access to information, primarily technical; c) production of information in amounts necessary and sufficient for life support and development of society in all its parts and directions; d) accelerated automatization and robotization in production and management; e) preferential development of informatization activities and services so that at least $50 \%$ of the employed work here [18. P. 22].

The universal nature of the current stage of informatization is manifested in the fact that in recent years the role of information has rapidly increased in almost all areas of society (economy, science, education, culture, health, politics, public and regional governance, national security). Informatization drastically changes traditional forms and methods of work organization and the structure of employment. The goal of Russia's transition to information society is the development of civil society and democratic traditions, and also overcoming information inequalities and Russia's entry into the global information society. The most important moral principle of information civilization should be the priority of the individual. 
Among important social consequences of informatization is the change in the nature of human labor. The main type of labor today is associated with the transformation of information flows. The power of human intelligence concentrated in the computer programs combines with the power of the individuals' brains. Thus, the usual task of using one's intellectual abilities when working with information technologies is transformed into the task of choosing and using various programs that allow to process and provide information necessary for decision-making and organization of practical activities in optimal time. The professional activity is significantly transformed, especially in material production, for automatization and robotics change the position of the person in the production system [12. P. 300-301]. Moreover, computer technologies allow to process information flows in any conditions, which leads to significant changes in the nature and values of professional activity.

Globalization of informatization lead to the change not only in the content of our knowledge but also in the ways it is acquired, reproduced and transferred, which significantly affects the internal structures of the individual and the process of forming values. Many researchers of personality emphasize that a personality formed by the previous school and type of higher education institution differs in its psychological characteristics from the one that plays computer games in kindergarten, goes to computer classes in school, works at a computerized workplace and communicates with friends via satellite. Under the new information technologies, the style of thinking, ways of communicating, assessing others and self-esteem are changing. On the one hand, one no longer feels lonely because he can quickly receive necessary information about all significant events. On the other hand, the problem of computer addiction becomes highly relevant.

The spread of the Internet raises the question of whether the media and computer network will be the main source of information in the coming years. The Internet, a global information computer network of the world wide web, unites a whole set of computer networks operating on the same rules and users all over the world. In the cyberspace communication, individual Internet users create and maintain certain patterns, norms and rules, "accumulate" certain social-cultural resources, build an information stratification system, i.e. create virtual network communities that become an important channel for promoting values. The Internet has become an integral part of the contemporary Russian society, which turned out to be not just a new piece of social contexture but a factor that changes social and cultural life in general under the influence of socialcultural dynamics [24. P. 427].

Despite the opportunities opening up for the individual, it would be wrong to present the prospects of the digital society in romantic and bright colors. It is necessary to understand dangerous trends of global informatization such as: increasing influence of the mass media; increasing penetration into the private life of people and organizations through information technologies, including computer crimes; increasingly complex problem of selecting reliable information; increasing gap between developers and consumers of information technology; intensification of the problem of the adaptation to information society [25. P. 382]. 
Despite the diversity of approaches, assessments and forecasts concerning information society, they mainly follow the same lines: communications and information technologies created a new situation in which, on the one hand, there are additional opportunities for progress, including solutions of worldviews contradictions, and, on the other hand, there is a growing number of problems determined by interference in the new society with inevitable consequences. Manifestations of information society are presented in the approval of the information picture of the world, changes in life and social world order based on the active and full use of knowledge in all social types of human activity, awareness of the unity of the laws of information in nature and society, their practical application, creation of industry of information production and processing, a significant transformation of traditional channels of formation of personal value preferences.

\section{Values of professional activity: concept and essence}

The objective conditions of contemporary development require a reorientation of society towards professionalism: in all spheres of labor activity, the human factor becomes the leading one. There is a growing interest in professionals - not only with high professional skills, but also with analytical, creative abilities, stable ideological and humanistic values. Professional morality develops in the professional work practices and is a feature of the humanistic maturity of the profession. Professionalism as the highest degree of skill and integrity of the individual is at the same time an expression of the general culture of the professional. The improvement of the professional activity requires not only the improvement of work tools and professional knowledge and skills, but also an increase in the moral and humanitarian culture. That is why the attitude of the professional to his business and colleagues is an expression of his moral socialization. One of the main factors in the choice of one's profession and development of professionalism are personal values that constitute the core of the worldview and reflect the attitude to oneself, the world around and other people [5].

In the scientific literature, values are interpreted differently: as significance, value of certain objects or processes, personal phenomena serving as the leading principles in life; as a value relationship; as one of the forms of existence of semantic forms; as an ideal model of the due indicating the desired transformation of reality; as the highest meaning of human existence, etc. [2. P. 19]. Thus, Rokeach defines values as stable beliefs in the fundamental preference of certain goals or ways of existence and distinguishes two classes of values: the first class includes values that are important for human life as a whole (main goals, final goals of personal existence), the second class consists of values preferred in any life situation, which corresponds to the traditional division of values-goals and values-means [19]. All definitions do not exclude but complement each other and are certainly subordinated: the system-forming value is defined through the value of objects, processes, phenomena to meet the needs of the subject; the definition of objects that have particular value acts as a value relation to them; the value of the object is detected through the evaluation of the object [2. P. 20]. Therefore, value is one of the key moral-oriented concepts representing a set of universal significant moral categories that act as standards of the due. 
According to P.S. Gurevich, it is the values that transform parts of reality into objects of culture and distinguish them from nature: "Values order reality ... They correlate not with the truth, but with the idea of an ideal, desired, normative" [8. P. 117]. Each culture, society, state, profession, and personality have ideas about the ideal and other values; there are also universal human values focused primarily on the preservation of the human race. Any social institution, including information, rely on values, and professional values reflect the meanings of the profession.

Professional values are the principles of professional behavior (and corresponding actions and attitudes of people) guided by the best examples of professional activity and associated with a deep understanding of its moral meaning and purpose [21. P. 265]. Values are a part of the worldview of professional communities, the way professional groups interact with various social situations. Social reality can be considered by the professional as an environment that needs to be transformed or, on the contrary, to be perceived as it is. Value expresses the relationship between the subject of professional activity and its object; it is the result of an assessment of certain objective properties of the profession in terms of their compliance with certain needs - existing or emerging - of the professional activity.

There are various types of professional values. Schwartz classifies professional values as: 1) internal (personal growth, autonomy, interest, creativity, etc.); 2) external (salary and security); 3) social (interaction with people and contribution to society); 4) power (prestige, authority, influence) [20]. E.I. Golovakha, by assigning values to the spheres of professional activity, identifies three groups of values: 1) realized only directly in professional activities, 2) through professional activities, and 3) only outside professional activities [7. P. 258]. A.A. Larionova-Krechetova distinguishes two groups of values: internal values are associated with relations of the subject of labor to the object of professional activity, its process and result, as well as with the personal qualities of the subject; external values are not directly related to the attitude to the components of professional activity but rather to factors external to professional work (social environment, working conditions, various attributes of professional activity and the accompanying lifestyle) [14. P. 5]. In the Western literature, professional values are considered through their influence on job satisfaction $[1 ; 3 ; 5 ; 6]$. For instance, there are five factors (groups of values) that affect job satisfaction: 1) internal values associated with the labor process (responsibility, duty, professionalism, satisfaction with the labor process); 2 ) internal values associated with the result of labor, i.e. its effectiveness (respect, professional status, approval, self-esteem); 3-5) external values that are not directly related to work (labor safety, salary satisfaction, career opportunities, communication, etc.) [3].

These classifications reveal different approaches to understanding the nature and essence of professional values and tend to distinguish a special group of internal professional values directly related to both the process of professional activity and the inner world of the individual with professional consciousness. However, these approaches do not take into account the fact that in professional activity, besides the proper professional values, there are also many other values associated with numerous relationships that develop in the course of professional activity (cognitive, aesthetic-moral, etc.). Thus, moral values exist for the professional both in the form of abstract theoretical knowledge 
and in the form of practical attitudes for making decisions and organizing professional behavior, i.e. moral values become guidelines for the individual in his professional work.

The value component is a part of the professional consciousness, which determines the possibility of moral evaluation of professional activity as the behavior of the specialist in the course of performing his professional duties. The value guidelines that professionals follow in the course of their activities and relationships are the main criterion for assessing the integrity of professional consciousness [22. P. 265]. In the course of its development universal moral ideals acquire a professionally oriented character according to the future profession. Thus, common moral values are filled with professional content according to the type of professional activity both in the course of professional activity and professional education [24].

\section{Professional values and moral culture of the professional}

The ability to form the right moral values determining moral behavior when performing professional duties is a part of the moral culture of the professional. This is a combination of socially recognized professional moral norms, principles, ideals and ways to translate them into the moral values of professional activities. The concept "moral culture" reflects the degree to which a person has mastered social moral experience, ability of consistent implementation of professional moral values in professional behavior and relationships, readiness for continuous professional and moral improvement [21. P. 72]. The moral culture of the professional consists of interrelated components united in the following groups: objective moral values - attitudes, norms, orientations to assess the objective correspondence of the professional behavior to the interests of both the professional group and society; subjective moral values elements of the developed professional and moral consciousness, attitudes and ideas about own profession, goals of the professional activity, professional and moral obligations to society; the diverse sphere of moral aspects of the professional activity motives, incentives, ways of professional activity corresponding to the social moral ideals [21. P. 75].

Moral motivation of professional activity is a prerequisite for professionalism. Any moral act, such as conscientious performance of official duties, can have different motives: a worker can show special diligence only for the fast career growth or as a result of the desire to demonstrate to his colleagues their professional failure; or his motives can be highly moral, and actions are morally conscious - guided by the desire to ensure public benefit, by the conviction of the necessity and social significance of his professional work. True professionalism has nothing to do with careerism, egoism, ostentatious morality, because it is based on moral values and humane moral convictions, awareness of one's duties to society, implementation of moral principles and norms in the professional behavior.

The development of the moral culture is the most important part of professionalization. It implies achievement of the optimal combination of traditional and creative elements, specific professional experience and the wealth of professional and public morality. From the ethical perspective, professionalism consists in the ability to ensure 
harmony of professional activity and its moral evaluation, readiness for worthy deeds in any professional situations. Therefore, professionalization implies development of mutual responsibility, loyalty to duty, tolerance, decency, and a focus on cooperation. Without these elementary principles, it is impossible to find freedom in creativity and self-realization. It is impossible to become a true professional without a professional worldview, ideals, dignity, respect for colleagues. Thus, the development of the professional depends largely on the formation of his value preferences for assessing the meaning of certain objects and events based on the needs and interests, ideals and aspirations of the subject. Such a system of value preferences is formed in the labor activities and reflected in the requirements and norms of the professional ethics: honest work for the benefit of society, moral relations in the field of direct contacts between the interests of professional groups with each other and with society, and following professional duty.

True professionalism presupposes a deep knowledge of the requirements of the professional morality. For the successful functioning within the profession, it is necessary to combine high professionalism with the deep awareness of the responsibility for the results of labor, readiness to perfectly fulfill one's professional duty. One of the most important regulators of professional activity and the criterion for assessing the development of the professional consciousness is professional conscience and professional duty.

\section{Basic moral values of professional activities: professional conscience, duty, responsibility}

Conscience is a moral and psychological regulator of human behavior. Together with duty, honor and dignity, it allows to realize one's moral responsibility to oneself as the subject of moral choice, to other people and to society as a whole. In the professional activities, an individual-personal moral mechanism of conscience is concretized depending on the social expectations to profession presented in the demand that the specialist's activities comply with professional values and ideals. As a moral value of professional activity, professional conscience is a kind of a fusion of rational awareness and sensory experience expressing a sense of moral satisfaction with work and deep emotional experiences in case of inability to fulfill professional duties. In other words, professional conscience makes the specialist fulfill and achieve excellence in his professional activities and expresses the moral responsibility of the specialist to himself as a subject of high professional values and requirements [22. P. 267]. The professional conscience regulates the behavior of the individual associated with his professional activity, determines his attitude to professional actions that can lead to psychological comfort and moral satisfaction. Awareness of a "clean" professional conscience expresses one's will to achieve professional excellence, internal integrity and fullness of professional consciousness, i.e. to become a professional.

Awareness of duty, just like conscience, plays the role of the moral-psychological mechanism of self-control. Such duty means "morally reasoned coercion to act; moral necessity fixed as a subjective principle of behavior" [22. P. 264]. Unlike conscience, duty is usually motivated in one way or another; it relies on consciousness and is a rational mechanism of self-consciousness. As a rule, duty is considered as subordination 
to society, awareness of duties, a method of socialization, and integration of the individual into society. However, professional duty reflects the professional and moral relation as the essence of any professional business and manifests in the prompting for actions necessary to carry out professional duties. Professional duty is closely related to public life and often defined in the broadest sense as the need to obey public morality such as duties to society, colleagues and oneself.

Duty is crucial for determining the value of professional activity in the Japanese labor culture being the foundation of the Japanese professional ethics. Duty presupposes a kind of internal immunity to all influences alien to personal ideological attitudes. A man of duty is not the one who can act morally but the one who cannot act differently; therefore, the category of duty cannot be defined only through the concept of duty. Responsibilities are something external to the person, their requirements are imposed from the outside, while duty is a moral condition determined by personal conscience, attitude to the world and other people based on the voluntary acceptance of certain responsibilities.

The professionally-due attitude to work is expressed primarily in the fact that the worker voluntarily and consciously performs his duties in the most optimal way for the given situation. A worker who has a sense of professional duty comes to the forefront of the social basis; his inner world is not a closed system of values but an open system facing outward; he realizes the need to maintain his reputation given his social status and role in the social system. For the professional, the harmony of public and personal is typical: the public acts as universal and corporate values, and the personal in accepting and following them. Thus, the objective side of professional duty is actual duties of the representative of the professional group, norms and principles underlying professional morality; the subjective side is the degree of personal awareness of these duties, their acceptance and creative fulfillment, self-determination of professional duty expressed in the desire to participate in the realization of professional ideals.

Awareness of professional duty often takes the form of professional responsibility - the relationship of a one's dependence on something perceived as the decisive basis for making decisions and taking actions. The high professionalism and civil maturity of the worker are manifested in the fact that his professional responsibility is recognized as a professional vocation and voluntarily accepted as a personal professional duty. It is the personality of the professional acting as the bearer of professional responsibility that is the guarantee of the qualitative fulfillment of professional duty. Professionalism implies a high degree of professional responsibility both for the results and the labor process itself. In turn, the growth of professionalism, the strengthening of professional self-realization and motivation of professional activity not only stimulates the growth of professional efficiency but also leads to an increase of responsibility for the results of professional activity and of job satisfaction. The sense of responsibility is almost equally related to high professional achievements and high integration into professional activities. On the contrary, poor achievements or integration into professional activities do not contribute to the sense of responsibility.

Professionalism involves the exact following of professional duty and responsibility for the process and results of professional activity [23]; therefore, professional honor 
and professional dignity are important characteristics of the professional moral and significant values of the professional activity. Professional dignity is a characteristic of the professional in terms of his compliance with his professional vocation and purpose. In its objective meaning, professional dignity reflects the place and role of the profession in public life: "Reflecting it in the professional consciousness... of the community creates a more or less stable idea of the importance of the profession for society, of recognizing this significance and, thus, acquires the character of a professional value which must be preserved as any value" [22. P. 266]. At the same time, professional dignity is subjective and evaluative in nature, i.e. reflected in the consciousness of the professional as an idea of one's importance in the profession, of one's significance for the professional community. In the structure of the personality, professional dignity acquires an imperative character: a person orders himself to be worthy.

The objective side of the professional dignity is reflected in the professional honor as a real relationship between the moral level of the profession and its public perception, i.e. it is the significance of the profession in the life of society and recognition of the professional dignity of the person by other people. Awareness of the importance of one's profession is an important driving force for the development of professionalism. Professional honor and professional dignity complement each other, support a certain, high level of professional and moral consciousness, thus, enhancing the moral component of professionalism.

There are also terms "professional justice", "professional tact", etc. Certainly, many moral values can be applied to the professional activity and serve as criteria for its moral evaluation. However, some values, such as professional duty or responsibility, are universal and extend to almost all types of professional activity, while others are local and manifested only in certain professions. Thus, professional justice is most relevant for the professional activities of lawyers and law enforcement officers, while professional tact - for professional and ethical codes of teachers, doctors, social workers, etc.

\section{Professional values in information society}

Today, a number of new moral values become an indispensable condition of effective activity and integrity of the moral world of the professional. The content and specificity of these values are determined by the highest moral requirements; they form the basis of the ethical code of the professional. For instance, the computer does not invent projects, it is the invention of man; therefore, the prospects for computerization depend primarily on the value-oriented attitudes of society. In the information era, the role of philosophy, whose main task since Plato's times has been the construction of ideal norms, goals and values of human life, significantly increases. Unfortunately, sometimes the goals of computerization are set by technocratic forces, and computer technologies are mainly used for industrial purposes as an instrument of war and domination, supervision and control, financial and administrative centralization, and to manipulate public opinion [25. P. 382]. Fetishization of information technologies is largely due to the reduction of all the wealth of humanity to operational-pragmatic side, and, consequently, to the denial of the spiritual-axiological aspect of human activity. 
In information society, a "perverse sector of the economy" has emerged and is growing, in which neither material nor spiritual values are created, and fictitious goods (social phantoms) are mainly reproduced to serve financial and other transactions. It is this field of activity that becomes the main area of "info communications", i.e. convergence of telecommunication and information services and technologies. As a result, the technological progress creates a 'perverse' sector and leads to an increase in social polarization. The key problem of social development in the information age "becomes the liberation of creative activity from the forms that are imposed on it in the wrong sector, the extrusion of this sector and the use of released resources for the progress of the creato-sphere - the world of culture, popular creative activity and, accordingly, the areas in which cultural values are created, the process of formation, upbringing, education and development of a person as a free, comprehensively developing personality is under way" [17. P. 133].

The most important principle of the professional moral culture is humanism respect for each human, understanding of his uniqueness, self-sufficiency. Humanism is based on respect for the rights, honor and dignity of others, recognition of the right of people to their own opinion, position and independency. True professionalism does not allow utilitarian perception of people - as a means to achieve any professional goals. Humanism, as a practical normative requirement of the professional ethics, insist on the priority of the individual. Moreover, humanism implies overcoming alienation in the professional labor, the possibility to choose one's profession and freedom in the professional creative activity.

Another essential feature of the contemporary and future professional is environmental friendliness of professional consciousness, i.e. he must consider himself as a part of nature capable of a reasonable impact on it. The harmonious interaction of man and nature suggests that man as a rational being spiritualize nature following the laws of their coexistence in the integral organic system. Today professionalism necessarily implies environmental literacy. However, considering the ecological compatibility of the consciousness of various professional groups, it is necessary to take into account that the share of environmental values in the value orientations can differ among different professions. For instance, the weight of ecological values in the group of the 'man-nature' professions is higher than in the 'the man-sign system' group [11]. Certainly, professionals in the field of 'man-nature' have careful attitude to living objects, while a high degree of abstraction of professionals in the field of 'man-sign system' does not allow to accept living as naturally as in the 'man-nature' professions. However, environmental values in the professional consciousness of the 'person-to-person' professions are also important. Professionalism in this area necessarily implies the ability of educating, participation in the moral education, whose main goal is the formation of a morally mature, socially active and comprehensively developed personality. A necessary component of the professional development today is becoming an environmentally competent person who can provide a truly moral relationship of man, society and nature.

The most important moral value of the professional should be the moral attitude to work including the moral equality of various types of professional activity. The prestige of certain professions in society should not be the basis for moral distinction and 
'public approval'. If a profession is socially beneficial, environmentally friendly and allows an individual to participate in social work, it is morally justified. So, in the contemporary Russian society, it is necessary to eliminate the prejudice against private entrepreneurship. At the same time, we need to develop moral condemnation to unfair, criminal, predatory labor without any morally positive value. And the moral attitude of the individual should be different to unequal professional activities based on the criterion of their professionalism.

Among the most important moral values of the professional today are moral reliability, professional optimism and patriotism. Moral reliability means the integrity and certainty of one's moral nature which leads to the stability of professional behavior. Moral reliability can be determined by (a) the unconditional devotion to the chosen profession, (b) the high normative regulation of behavior represented by the ability of the conscious implementation of duty, (c) the knowledge of the spiritual potential of the whole cultural system of the due and good, (d) the complex of such qualities of the professional as being active, principled, self-sacrificing, conscientious, sincere, loyal, honest, humane and responsible. Professional optimism implies confidence in achieving the desired results of professional work and is based on the high professionalism. Its another important value today is patriotism - the desire to contribute to the development and prosperity of one's country by professional work.

Informatization of the economy and culture, increasing requirements to qualifications and professional competence make us consider professionalism as a measure of the specialist's skills and one of the most important values of professional activity. However, the very concept of professionalism should not be limited to the sum of purely professional knowledge and skills. A true professional has a developed, based on value orientations, moral culture, deep understanding of his professional duty, the most scrupulous attitude to issues of professional honor, and a high professional responsibility. Moral values of professional activity - mutual responsibility, loyalty to duty, tolerance, decency, and focus on cooperation - are formed in the process of professionalization. Subsequently, in the course of professional work, professional conscience, duty, dignity, tact, etc. are formed. The success of professional activities, the integrity of the specialist's personality and his creative self-expression in the chosen profession depend on how well his professional and moral principles are combined.

\section{References}

[1] Abbott A. The order of professionalization. An empirical analysis. Work and Occupations, 1991; 18 (4).

[2] Bayluk V.V. Tsennosti professionalnoi samorealizacii lichnosti [Values of professional selfrealization of personality]. Pedagogicheskoe Obrazovanie v Rossii. 2015; 3 (In Russ.).

[3] Bardi A., Lee J.A., Towfigh N., Soutar G. The structure of intra-individual value change. Journal of Personality and Social Psychology. 2009; 97.

[4] Vasilieva Z.I. Gumanisticheskie tsennosti obrazovaniya i vospitaniya (90-e gg. XX v Rossiya). [Humanistic values of education and upbringing (the $90 \mathrm{~s}$ of the $20^{\text {th }}$ century in Russia)]. Saint Petersburg; 2003 (In Russ.). 
[5] Evens J. Reinterpreting professionalism as a discourse of social control and occupational change. Svensonl L., Evetts J. (Eds.) Conceptual and Comparative Studies of Continental and AngloAmerican Professions. Goteborg; 2003.

[6] Forsyth P.B., Danisiewicz T.J. Toward a theory of professionalization. Work and Occupations. $1985 ; 12(1)$.

[7] Golovakha E.I. Zhiznennaya perspektiva i tsennostnye orientatsii lichnosti. [The life perspective and personal value orientations]. Psihologiya lichnosti v trudah otechestvennyh psihologov. Sost. L.V. Kulikov. Saint Petersburg; 2000 (In Russ.).

[8] Gurevich P.S. Filosofiya kultury [Philosophy of Culture]. Moscow; 1995 (In Russ.).

[9] Larson M. The Rise of Professionalism: A Sociological Analysis. Berkeley-London; 1977.

[10] Kagan M.S. Filosofskaya teoriya tsennosti [Philosophical Theory of Value]. Saint Petersburg; 1997 (In Russ.).

[11] Kalita V.V. Ekologichnost soznaniya professionala [Environmentality of the professional's consciousness]. Avtoref.t dis. ... k.p.n. Moscow; 1996 (In Russ.).

[12] Colin K.K. Filosofskie problemy informatiki [Philosophical Problems of Computer Science]. Moscow; 2010 (In Russ.).

[13] Kostenko N.V., Ossovsky V.L. Tsennosti professionalnoi deyatelnosti [Values of Professional Activity]. Kiev; 1986 (In Russ.).

[14] Larionova-Krechetova A.A. Dinamika tsennostno-smyslovoi sfery professionalnoi deyatelnosti $\mathrm{v}$ protsesse stanovleniya sub'ekta truda [Dynamics of the value-semantic sphere of professional activity in the formation of the subject of labor]. Avtoref. dis... k.p.n. Moscow; 2005 (In Russ.).

[15] Lebedeva N.M., Tatarko A.N. Tsennosti kultury i razvitie obshestva [Values of Culture and Development of Society]. Moscow; 2007 (In Russ.).

[16] McClelland C. The German Experience of Professionalization. Cambridge; 1991.

[17] Mantatova L.V. Strategiya razvitiya: Tsennosti novoi tsivilizatsii. [Development Strategy: Values of a New Civilization]. Ulan-Ude; 2004 (In Russ.).

[18] Rakitov A.I. Filosofiya kompyuternoi revolyutsii [Philosophy of the Computer Revolution]. Moscow; 1991 (In Russ.).

[19] Rokeach V. The Nature of Human Values. New York; 1973.

[20] Schwartz S.H. Culture matters. C.-Y. Chiu, Y.Y. Hong, S. Shavitt, R.S. Wyer (Eds.) Understanding Culture: Theory, Research and Application. New York; 2009.

[21] Tsvyk V.A. Nravstvennaya kultura professionala [The moral culture of the professional]. RUDN Journal of Philosophy. 2015; 2 (In Russ.).

[22] Tsvyk V.A. Nravstvennye tsennosti professionalnoi deyatelnosti [Moral values of the professional activity]. Lichnost. Kultura. Obshestvo. 2014; XVI (1-2) (In Russ.).

[23] Tsvyk V.A., Mukhametzhanova V.S. Ethical basis of professionalism. 3rd International Conference on Arts, Design and Contemporary Education. Atlantis Press; 2017.

[24] Tsvyk V.A., Tsvyk I.V. Professional development in information society: Challenges and prospects. RUDN Journal of Sociology, 2018; 18 (3).

[25] Tsvyk I.V. Kompyuternye tehnologii v sovremennom obrazovatelnom protsesse: etichesky aspekt [Computer technologies in the contemporary educational process: An ethical aspect]. RUDN Journal of Philosophy. 2017; 21 (3) (In Russ.).

[26] Tsennosti kultury i modeli ekonomicheskogo povedeniya [Values of Culture and Models of Economic Behavior]. Pod red. N.M. Lebedevoi, A.N. Tatarko. Moscow; 2011 (In Russ.).

[27] Shalova S.Yu. Professionalnye tsennosti v sisteme tsennostnyh orientatsii studentov pedvuza [Professional values in the system of value orientations of the teacher training university's students]. Naukovedenie. 2013; 3 (In Russ.).

[28] Tsvyk V.A., Tsvyk I.V. et al. Etika vysshei shkoly [Ethics of Higher Education]. Moscow; 2016 (In Russ.). 


\title{
Нравственные ценности профессиональной деятельности в информационном обществе*
}

\author{
В.А. Цвык ${ }^{1}$ И.В. Цвык ${ }^{1,2}$ \\ ${ }^{1}$ Российский университет дружбы народов \\ ул. Миклухо-Маклая, 6, Москва, 117198, Россия
}

${ }^{2}$ Московский авиационный институт (национальный исследовательский университет)

Волоколамское шоссе, 4, Москва, 125993, Россия

(e-mail: tsvyk-va@rudn.ru; tsvykirina@mail.ru)

В статье предпринята попытка на основе системного подхода выявить нравственные ценности профессиональной деятельности в условиях информационного общества. Процесс информатизации в XXI веке перешел на качественно новый этап развития: информационная среда нацеливает на формирование определенных мировоззренческих и аксиологических приоритетов, в соответствии с которыми изменяются и ценностные характеристики информационного общества. Одной из важнейших ценностных сфер в информационном обществе становится профессиональная деятельность. Ее нравственные ценности - взаимная ответственность, верность долгу, терпимость, порядочность, нацеленность на сотрудничество - формируются в процессе профессионализации личности. Впоследствии в ходе профессионального труда формируются профессиональная совесть, долг, ответственность, достоинство, такт и др. Кроме того, важнейшей нравственной ценностью профессиональной деятельности является профессионализм, который не следует ограничивать суммой чисто профессиональных знаний и навыков. Подлинный профессионал обладает цельной, развитой, основывающейся на ценностных ориентациях нравственной культурой, реализующейся в глубоком понимании своего профессионального долга, в щепетильном отношении к вопросам профессиональной чести, в профессиональной ответственности. От того, насколько слиты в человеке профессиональные и нравственные начала, насколько они едины и согласованы, зависит успех его деятельности, цельность личности, мера творческого самовыражения в профессии. Задача формирования ценностей профессиональной деятельности работника - важнейшая часть профессионализации личности: она заключается в том, чтобы достичь оптимального сочетания традиционного и творческого элементов, соединить профессиональный опыт личности с богатством профессиональной и общественной морали. С этической точки зрения профессионализм состоит в способности обеспечить гармонию профессиональной деятельности и ее нравственной оценки, готовность к достойным поступкам в любых профессиональных ситуациях.

Ключевые слова: ценности; профессиональная деятельность; информационное общество; нравственные ценности; профессионализм; профессионализация личности; профессиональная совесть; профессиональный долг; профессиональная ответственность

* ( С) Цвык В.А., Цвык И.В., 2019.

Статья подготовлена при поддержке РУДН. Проект № 101404-0-000.

Статья поступила 04.05.2019 г. Статья принята к публикации 07.06.2019 г. 